\title{
ANALISIS PEMAHAMAN SISWA TERHADAP NILAI-NILAI PANCASILA PADA PEMBELAJARAN PENDIDIKAN KEWARGANEGARAAN KELAS XI SEKOLAH MENENGAH ATAS NEGERI 1 KETUNGAU TENGAH TAHUN PELAJARAN 2019/2020
}

\author{
Juri, Septha Suseka, Apoy \\ STKIP Persada Khatulitiwa, Program Studi Pendidikan Pancasila dan Kewarganegaraan \\ E-mail: jurisaputra85@gmail.com,cekgupapakebenaran@gmail.com,
}

\begin{abstract}
The purpose of this study was to describe the Students' Understanding of the Pancasila Values in the Learning of Citizenship Education in Class XI School 1 Ketungau Tengah. To describe it through the formation of school hours and implement it in the school environment in accordance with the values of Pancasila learned in the learning of Citizenship Education in State Middle School 1 Ketungau Tengah, to describe the supporting and inhibiting factors. The method used in this research was qualitative descriptive with case study research. Then the techniques used for data collection were observation, interview, and documentation techniques. The results in this study indicate that: 1) Students' understanding of Pancasila Values through the Citizenship Education learning process by trying to apply it in the school environment and applying it in accordance with the Learning Implementation Plan. 2) instilling the values of Pancasila to follow the flag ceremony every Monday and when commemorating national holidays, group work. 3) supporting factors realize the vision and mission of the school by implementing school rules with the principal's policy. The inhibiting factor was that students do not understand and have no intention of applying the values of Pancasila that should be applied, although it has been directed by their teacher their lack of concern for the teacher and the values of the Pancasila, so that they obstruct the application and instillation of the values of the Pancasila, then from they need to understand more deeply the values of the Pancasila in order to implement and instill them in the school environment.
\end{abstract}

Keywords: Students' Understanding, Pancasila Values 


\begin{abstract}
Abstrak
Tujuan dalam penelitian ini untuk mendeskripsikan Pemahaman Siswa Terhadap Nilai-nilai Pancasila Pada Pembelajaran Pendidikan Kewarganegaraan Kelas XI Sekolah Menengah Atas Negeri 1 Ketungau Tengah. Untuk mendeskripsikannya melalui pembinaan jam sekolah dan menerapkannya di lingkungan sekolah sesuai dengan nilai-nilai Pancasila yang dipelajari pada pembelajaran Pendidikan Kewarganegaraan di Sekolah Menengah Atas Negeri 1 Ketungau Tengah, untuk mendeskripsikan faktor pendukung dan penghambat. Metode yang digunakan dalam penelitian ini adalah deskriftif kualitatif dengan bentuk penelitian studi kasus. Kemudian teknik yang digunakan untuk pengumpulan data yaitu teknik observasi, wawancara, dan dokumentasi. Hasil dalam penelitian ini menunjukan bahwa: 1) Pemahaman siswa terhadap Nilainilai Pancasila melalui proses pembelajaran Pendidikan Kewarganegaraan dengan mencoba menerapkannya di lingkungan sekolah dan menerapkannya sesuai dengan Rencana Pelaksanaan Pembelajaran. 2) menanamkan nilai-nilai Pancasila mengikuti upacara bendera setiap hari senin maupun saat memperingati hari besar nasional, kerja kelompok. 3) faktor pendukung mewujudkan visi misi sekolah dengan menerapkan tata tertib sekolah dengan adanya kebijakan kepala sekolah. Faktor penghambatnya siswa belum mengerti dan tidak mempunyai niat dalam menerapkan nilainilai Pancasila yang seharusnya diterapkan, meskipun sudah diarahkan oleh gurunya kurangnya rasa peduli mereka terhadap guru dan nilai-nilai Pancasila tersebut, sehingga menghamat penerapan dan penanaman nilai-nilai Pancasila tersebut, maka dari itu perlu lebih dalam mereka memahami nilai-nilai Pancasila tersebut guna untuk menerapkan dan menanamkannya di lingkungan sekolah.
\end{abstract}

Kata kunci: Pemahaman Siswa, Nilai-nilai Pancasila. 


\section{A. Pendahuluan}

Pancasila merupakan suatu dasar Negara Kesatuan Republik Indonesia (NKRI) yang dimana terdapat lima sila. Pancasila disahkan sebagai dasar negara setelah melakukan sidang BPUKI pertama Pada tanggal 1 Juni 1945, kemudian Indonesiamemproklamasikan kemerdekaannya pada tanggal 17 Agustus 1945, pada tanggal 18 Agustus 1945 disahkan UndangUndang Dasar 1945 termasuk pembukaan UUD 1945 dimana termuat isi rumusan lima prinsip atau lima prinsip sebagai suatu dasar negara yang diberi nama Pancasila. Berdasarkan kalimat di atas yang dimana Indonesia menyatakan bahwa Pancasila merupakan suatu dasar negara atau Ideologi dasar dalam kehidupan besar bagi negara Indonesia, sedangkan nilai merupakan sesuatu hal yang dianggap penting atau berguna bagi masyarakat dan merupakan tujuan yang ingin dicapai. Hal ini mengandung arti bahwa pemahaman nilai-nilai Pancasila sangatlah penting dipahami oleh dikalangan manapun terlebih khusus oleh siswa sebagai generasi penerus bangsa.

Sebagai negara yang memiliki keanekaragaman suku, ras, agama, dan wilayah yang sangat luas terdiri atas ribuan pulau, bangsa Indonesia sudah seharusnya memiliki rasa persatuan yang tinggi guna mempererat tali persaudaraan, kesejahteraan, perdamaian dan keadilan sosial, sesuai dengan Bhineka Tunggal Ika, guna melaksanakan dan menanamkan nilai-nilai Pancasila di Negara Kesatuan Republik Indonesia (NKRI).

Nilai-nilai Pancasila yang seharunya menjadi tujuan dan citacita bangsa sudah tidak berjalan dengan semestinya, karena masih banyak contoh yang tidak menunjukan penanaman dan pelaksanaan nilai-nilai Pancasila tersebut, tidak lain dilakukan oleh petinggi-petinggi negara dikarenakan perbedaan kepercayaan dan perbedaan politik. Akhir-akhir ini banyak yang menghianati Pancasila tersebut dikarenakan haus akan kekuasaan sehingga dapat melakukan 
segala cara demi mendapatkan apa yang mereka inginkan.

Namun hal ini sudah tidak berjalan dengan semestinya seperti yang diharapkan oleh pejuang terdahulu atau pemerintah. Nilai-nilai Pancasila yang seharunya menjadi tujuan dan cita-cita bangsa sudah tidak berjalan dengan semestinya, karena masih banyak contoh yang tidak menunjukan penanaman dan pelaksanaan nilai-nilai Pancasila tersebut, tidak lain dilakukan oleh petinggi-petinggi negara dikarenakan perbedaan kepercayaan dan perbedaan politik.

Akhir-akhir ini bangsa Indonesia sangat dihadapkan hal yang sangat buruk dalam mempertahankan Pancasila akibat dari perbedaan-perbedaan di atas. Indonesia memiliki ancaman yang sangat besar yaitu terkait dengan Pancasila sebagai ideologi bangsa. Pancasila yang sudah lama disahkan oleh pemerintah sebagai dasar negara, yaitu sejak kemerdekaan Indonesia, akan tetapi saat ini ideologi negara tesebut menjadi ancaman besar bagi pemerintah dan masyarakat lainnya. Dalam hal ini sudah sangatlah nampak bahwa tidak sejalan dengan nilai-nilai Pancasila yang sudah diperjuangkan oleh para pahlawan dari sejak zaman penjajahan, dikarenakan banyak oknum yang tidak bertanggung jawab dan tidak profesional dalam berpolitik, sehingga bisa melakukan apapun guna mencapai bermacammacam kekuasaan. Pada hakikatnya hal ini tidak perlu terjadi terus menerus, untuk hal itu kita harus mengkajinya salah satunya adalah dari segi pemahaman nilai-nilai Pancasila melalui pembelajaran Pendidikan Kewarganegaraan.

Dengan melihat hal tesebut, maka sangatlah penting bagi siswasiswi yang dianggap sebagai generasi penerus bangsa untuk memahami arti nilai-nilai Pancasila tersebut, guna menciptakan pemimpin yang cerdas, kritis, disiplin, serta dapat bertanggung jawab dalam melakukan dan menanggapi hal apapun dan dapat mengatasi hal apapun yang dapat merugikan bangsa Indonesia. Untuk mengantisipasi hal itu, pemahaman siswa perlu lebih dalam memahami arti penting dari nilainilai Pancasila yang dimana di dalam ISSN: 2540 - 8038 
nilai-nilai tersebut mengatur norma, etika, moralitas (tingkah laku manusia) yang harus diterapkan dan kita pahami apalagi Pancasila adalah dasar negara kita sendiri (Indonesia).

Pemerintah dan masyarakat umum sangat mengharapkan perilaku yang lebih baik, maupun sopan seperti yang tercantum di dalam Undang-Undang Dasar RI No. 20 Tahun 2003 Bab 2 Pasal 3 tentang Pendidikan Nasional disebutkan bahwa:

"Pendidikan nasional berfungsi mengembangkan kemampuan dan membentuk watak serta peradaban bangsa yang bermartabat dalam rangka mencerdaskan kehidupan bangsa, bertujuan untuk berkembangnya potensi peserta didik agar menjadi manusia yang beriman dan bertaqwa kepada Tuhan Yang maha Esa, berakhlak mulia, sehat, berilmu, cakap, kreatif, mandiri dan menjadi warga negara yang demokratis serta bertanggung jawab".

Pemahaman siswa-siswi yang

lebih dalam mengenai Nilai-nilai Pancasila tentu menjadi harapan besar pemerintah dan masyarakat umum untuk menjadi pemimpin yang jujur, bertanggung jawab, berintergritas dan disiplin tinggi dan menjadi teladan bagi generasi berikutnya. Banyak dampak yang bisa timbul akibat kurangnya pemahaman nilai-nilai Pancasila, misalnya siswa tidak menghargai perbedaan agama, tidak menjunjung tinggi nilai kemanusiaan, tidak menjaga persatuan, tidak menghargai pendapat orang lain, memaksakan hak orang lain. Jika hal itu terus berlanjut maka maka tentu akan menjadi masalah dalam kemajuan sumber daya manusia yang berkualitas dan berdaya saing.

Banyak hal yang bisa terjadi jika siswa tidak memahami apa itu yang terkandung dan yang harus dijalankan dan ditanamkan menurut materi nilai-nilai Pancasila, misalnya pengkriminalisasi antara siswa dengan siswa ataupun siswa dengan guru akibat suatu perbedaan, tidak adilnya seorang guru dalam memberikan penilaian di sekolah, misalnya masih memendang keluarga sendiri atau bukan, pilih kasih, terjadi ketidakcocokan antara siswa dengan siswa yang lain karena kurangnya pemahaman tentang nilainilai Pancasila yang menjelaskan 
inti-inti penting dalam nilai-nilai Pancasila tersebut.

Dalam penelitian yang dilaksanakan di SMA Negeri 1 Ketungau Tengah, peneliti tertarik mengenai nilai-nilai Pancasila, dengan berdasarkan informasi dan kenyataan-kenyataan yang dilihat oleh peneliti pada saat melakukan pra observasi, sikap yang menunjukan nilai-nilai Pancasila pada lingkungan sekolah masih sangat kurang, apalagi jika melihat kemajuan zaman, pengaruh politik, kebebasan dan pendidikan di kota. Hal jangan sampai hal ini terus berlanjut dan ditiru oleh siswa-siswi di SMANegeri 1 Ketungau Tengah, yang seharusnya siswa-siswi dianggap sebagai generasi penerus bangsa jangan sampai meniru atau menuju ke hal yang negatif dan mempengaruhi mutu pendidikan.

Dengan melihat hal di atas maka pemerintah memberikan kesempatan kepada anak-anak bahkan setiap manusia untuk memperoleh kesempatan untuk mendapatkan pendidikan dan pengajaran, demi tercapainya tujuan dan cita-cita bangsa, untuk memajukan kesejahteraan umum, mencerdaskan kehidupan bangsa, dan ikut melaksanakan ketertiban dunia sesuai seperti yang tercantum pada pembukaan UUD 1945.

Kemudian hal lainya yang membuat peneliti tertarik melaksanakan penelitian di SMA Negeri 1 Ketungau Tengah tersebut adalah karena sekolahnya berdekatan dengan perbatasan IndonesiaMalaysia. Bagi masyarakat semangat dalam mencintai negara kita sendiri (Indonesia) sudah mulai menurun akibat pengaruh perperangan politik dan agama. Hal ini adalah hal yang paling utama harus mendapat perhatian guna terjaganya cita-cita bangsa. Berdasarkan hal tersebut betapa pentingnya pembinaan siswasiswi untuk memahami arti penting nilai-nilai Pancasila melalui pembelajaran Pendidikan Kewarganegaraan.

\section{B. Metode}

Berdasarkan pendekatan, secara garis besar dibedakan menjadi dua macam penelitian, yaitu penelitian kuantitatif dan kualitatif. Pada penelitian kali ini, pendekatan ISSN: 2540 - 8038 
yang digunakan adalah dengan menggunakan penelitianstudi kasus. Sugiyono (2015: 15) mengatakan metode penelitian kualitatif adalah metode penelitian yang berlandaskan pada filsafat posititivisme, digunakan untuk meneliti pada kondisi obyek yang alamiah, (sebagai lawannya adalah eksperimen) dimana peneliti adalah sebagai instrument kunci (key intrument), pengambilan sampel sumber data dilakukan secara purposive dan snowball, teknik pengumpulan dengan triangulasi (gabungan), analisis dan bersifat induktif atau kualitatif, dan hasil penelitian kualitatif lebih menekan makna dari pada generalisasi.

\section{Sugiyono (2016:} berpendapat bahwa metode penelitian pada dasarnya cara ilmiah untuk mendapatkan data dengan tujuan dan kegunaan tertentu. Berdasarkan hal tersebut terdapat empat empat kata kunci yang perlu diperhatikan yaitu, cara ilmiah, data, tujuan, dan kegunaan. Cara ilmiah berarti kegiatan penelitian itu didasarkan pada ciri-ciri keilmuan, yaitu rasional, empiris, dan sistematis. Rasional berarti kegiatan penelitian itu dilakukan dengan caracara yang masuk akal, sehingga terjangkau oleh penalaran manusia. Empiris berarti cara-cara yang dilakukan itu dapat diamati oleh indera manusia, sehingga orang lain dapat mengamati dan mengetahui cara-cara yang digunakan. (Bedakan cara yang tidak ilmiah, misalnya mencari uang yang hilang, atau provokator, atau tahanan yang melarikan diri melalui paranormal). Sistematis artinya, proses yang digunakan dalam penelitian itu menggunakan langkah-langkah tertentu yang bersifat logis.

Rahardjo \& Gudnanto (2011: 250) mengatakan studi kasus adalah suatu metode untuk memahami individu yang dilakukan secara integrative dan komprehensif agar diperoleh pemahaman yang mendalam tentang individu tersebut beserta masalah yang dihadapinya dengan tujuan masalahnya dapat terselesaikan dan memperoleh perkembangan diri yang baik. Pendapat serupa di sampaikan oleh Walgito (2010: 92) bahwa studi kasus merupakan suatu metode untuk menyelidiki atau mempelajari suatu ISSN: 2540 - 8038 
kejadian mengenai perseorangan (riwayat hidup). Pada metode studi kasus ini diperlukan banyak informasi guna mendapatkan bahanbahan yang agak luas.Metode ini merupakan integrasi dari data yang diperoleh dengan metode lain.

Nuryaman \& Christina ( 2015:

5) menjelaskan bahwa objek penelitian adalah karakteristik yang melekat pada subjek penelitian. Karakteristik ini jika diberikan nilai maka nilainya akan bervariasi (berbeda) antar individu suatu dengan yang lainnya. Dalam suatu penelitian, objek penelitian dinamakan variabel penelitian. Adapun dalam penelitian ini yang dijadikan objek penelitian adalah siswa kelas XI SMA Negeri 1 Ketungau Tengah. Alasan dipilihnya lokasi tersebut karena letaknya berdekatan langsung dengan perbatasan (Malaysia) serta masalah yang diangkat dalam penelitian ini berkaitan dengan pemahaman nilainilai Pancasila dengan berdasarkan pada saat penelitian yang dilakukan serta ditemukan masalah yang berkaitan dengan pemahaman nilainilai Pancasila masih terbilang kurang. Hal ini sudah terlihat dari kurangya kesadaran siswa dalam mengikuti aturan atau tata tertib sekolah, misalnya bolos saat upacara bendera, hal ini juga sangat nampak contohnya dalam hal kecil banyak terjadi diskriminasi dan perbedaan yang sering diperdebatkan oleh siswa/i tersebut. Penelitian ini dilaksanakan di SMA Negeri 1 Ketungau Tengah, Kecamatan Ketungau Tengah, Kabupaten Sintang.

Sugiyono (2011: berpendapat bahwa teknik pengumpulan data merupakan langkah yang paling strategis dalam penelitian, karena tujuan utama dari penelitian adalah mendapatkan data.

a. Teknik Observasi

Hadi dalam Sugiyono (2013: 145) mengemukakan bahwa observasi menrupakan suatu proses yang kompleks, suatu proses yang tersusun dari berbagai proses biologis dan psikologis. Dua diantara yang terpenting adalah proses-proses pengamatan dan ingatan.

b. Teknik Wawancara

Menurut Sugiyono (2010:194) wawancara digunakan sebagai teknik ISSN: 2540 - 8038 
pengumpulan data apabila peneliti akan melaksanakan studi pendahuluan untuk menemukan permasalahan yang harus diteliti, dan juga peneliti ingin mengetahui hal-hal dari responden yang lebih mendalam dan jumlah respondennya sedikit/kecil.

c. Teknik Dokumentasi

Sugiyono (2013: 240) mengatakan bahwa dokumen merupakan catatan peristiwa yang sudah berlalu. Dokumen bisa berbentuk tulisan, gambar, atau karya-karya monumental dari seorang. Dokumen yang berbentuk tulisan misalnya catatan harian, sejarah, kehidupan (life histories) ceritera, biografi, peraturan, kebijakan. Dokumen yang berbentuk gambar, misanya foto, gambar hidup, sketsa dan lain-lain.

Sugiyono (2011: menjelaskan bahwa instrumen atau alat penelitian adalah peneliti itu sendiri. Oleh karena itu, peneliti sebagai instrumen juga harus "divalidasi" seberapa jauh peneliti kualitatif siap melakukan penelitian yang selanjutnya terjun ke lapangan.Sugiyono (2011: 222) menjelaskan bahwa instrumen atau alat penelitian adalah peneliti itu sendiri. Oleh karena itu, peneliti sebagai instrumen juga harus "divalidasi" seberapa jauh peneliti kualitatif siap melakukan penelitian yang selanjutnya terjun ke lapangan.. Adapun instrumen pengumpulan data dalam penelitian ini adalah:

a. ObservasiSugiyono (2016: 145) mengatakan bahwa observasi sebagai teknik pengumpulan data mempunyai ciri khas yang spesifik bila dibandinkgan dengan teknik yang lain, yaitu wawancara dan kuesioner selalu berkomunikasi dengan orang, maka observasi tidak terbatas pada orang, tetapi juga obyek-obyek alam yang lain.

Teknik pengumpulan data dengan

observasi digunakan bila, penelitian berkenaan dengan perilaku manusia, proses kerja, gejala-gejala alam dan bila responden yang diamati tidak terlalu besar. Dari segi proses pelaksanaan pengumpulan data, observasi dapat dibedakan menjadi participant observation (observasi berperan serta) dan non participant observation. Adapun yang dilakukan ISSN: 2540 - 8038 
oleh peneliti dalam tahap observasi yaitu dengan melakukan observasi terhadap siswa dan guru PPKn di SMA Negeri 1 Ketungau Tengah.

b. Wawancara

Effendi \& Tukiran (2012: 207) wawancara merupakan suatu proses interaksi dan komunikasi. Dalam proses ini, hasil wawancara ditentukan oleh beberapa faktor yang berinteraksi dan memengaruhi arus informasi. Faktor-faktor tersebut adalah pewawancara, responden, topik penelitian yang tertuang dalam daftar pertantyaan, dan situasi wawancara. Adapun tahap yang dilakukan oleh peneliti dalam tahap wawancara, yaitu dengan melakukan wawancara dengan wakil kepala sekolah, guru PKn, dan siswa kelas XI SMA Negeri 1 Ketungau Tengah.

\section{c. Dokumentasi}

Menurut Arikunto (2010: 274) metode dokumentasi yaitu mencari data mengenai hal-hal atau variabel yang berupa catatan, transkip, buku, surat kabar, majalah, dan sebagainya. Selanjutnya menurut Sugiyono (2016: 329) teknik dokumentasi merupakan pelengkap dari penggunaan metode observasi dan wawancara dalam penelitian kualitatif. Adapun yang dilakukan dan diperoleh peneliti yaitu dengan meminta dokumen sekolah dari wakil kepala sekolah, mengambil gambar dari guru, siswa kelas XI, dan profil SMA Negeri 1 Ketungau Tengah.

\section{Pembahasan Dan Hasil}

Berdasarkan hasil penelitian yang dilaksanakan di SMA Negeri 1 Ketungau Tengah ini berada di Kecamatan Ketungau Tengah, di Nanga Merakai, tepatnya di Kelurahan Senangan Kecil. Sekolah ini berdekatan langsung dengan perbatasan (Indonesia-Malaysia). Adapun hasil observasi terhadap guru yang dilakukan oleh peneliti bekaitan dengan kegiatan pembelajaran, serta upaya penerapan yang dilakukan oleh guru PKn terkait dengan pemahaman siswa terhadap nilai-nilai Pancasila.Upaya yang dilakukan oleh guru PKn dalam kegiatan pembelajaran PKn, meliputi: 1) Menanamkan nilai-nilai Pancasila yang dikembangkan dan dijelaskan dalam pembelajaran PKn yang dilaksanakan sesuai dengan RPP. 2) Menanamkan nilai-nilai ISSN: 2540 - 8038 
Pancasila di lingkungan sekolah, dengan cara berpakaian bergaul dengan teman. 3) Menanamkan rasa cinta tanah air dan nilai nasionalisme serta patriotisme yang tinggi (mengikuti upacara bendera yang dilaksanakan atau dilakukan setiap hari Senin, membacakan pembukaan UUD Negara Republik Indonesia 1945, dan membacakan teks Pancasila serta menyanyikan lagu kebangsaan. 4) Menanamkan nilainilai Pancasila pada lingkungan sekolah contohnya mentaati tata tertib sekolah.

a. Upaya penerapannya di lingkungan sekolah yang meliputi: 1) Guru mengharuskan siswa untuk mengikuti upacara bendera setiap hari Senin.

2) Guru mengarahkan siswa untuk ikut serta dalam memperingati hari besar nasional.

3) Guru mengarahkan siswa untuk kerja kelompok.

4) Menanamkan rasa saling menghormati antar agama sesuai sila yang pertama Ketuhanan Yang Maha Esa, contohnya mempunyai serta meyakini suatu agama menjalankan perintah-Nya dan menjauhi larangan-Nya sesuai agama dan kepercayaan yang dianut.

5) Guru mengajarkan dan mengarahkan siswa supaya mengembangkan sikap saling tenggang rasa dan selira, yang tercantum pada sila yang kedua, contohnya mau mengikuti kerja bakti di sekolah.

6) Guru meminta siswa mengembangkan sikap atas dasar persatuan atas dasar Bhineka Tunggal Ika sesuai dengan sila yang ketiga Persatuan Indonesia, contohnya siswa tidak membedabedakan suku, ras, agama satu dengan yang lainnya.

7) Siswa tidak boleh memaksakan kehendak orang lain sesuai dengan isi butir sila keempat Kerakyatan yang dipimpin Oleh Hikmat Kebijaksanaan dalam Permusyawaratan Perwakilan, contohnya tidak boleh memaksakan kehendak sendiri terhadap orang lain apalagi yang bersifat ancaman.

8) Siswa mengembangkan sikap adil terhadap sesama, sesuai dengan butir sila kelima keadilan sosial ISSN: 2540 - 8038 
bagi seluruh rakyat Indonesia, contohnya adil terhadap teman yang membutuhkan bantuan dan tidak membeda bedakannya.

9) Guru menyerahkan aktivitas belajar mengajar sendiri tanpa arahan dari guru.

10) Guru tidak memberikan kesempatan siswa untuk bertanya.

\section{1) Guru memberikan} kesempatan siswa untuk bertanya menjawab mengenai materi yang sudah disampaikan.

12) Guru membiarkan siswa yang tidak aktif di kelas.

13) Guru selalu memberikan gambaran jawaban jika siswa tidak bisa menjawab pertanyaan yang diberikan guru.Adapun hasil observasi terhadap siswa terhadap nilai-nilai Pancasila yang dilakukan oleh peneliti, yaitu mengenai sila yang pertama sampai dengan sila yang kelima

a) Ketuhanan Yang Maha Esa

1) Berdoa menurut kepercayaan masing-masing sebelum memulai pelajaran.

2) Sikap yang baik sesuai dengan kepercayaannya.
3) Siswa menghargai perbedaan agama.

4) Memiliki fasilitas tempat ibadah.

b) Kemanusiaan Yang Adil dan Beradap

1) Siswa mengembangkan sikap saling mencintai sesama manusia.

2) Siswa tidak menjunjung tinggi nilai kemanusiaan.

3) Siswa tidak mengembangkan sikap semena-mena terhadap orang lain baik guru ataupun teman sebaya.

4) Siswa mengembangkan sikap hormat menghormati dan bekerjasama.

c) Persatuan Indonesia

1) Siswa mengembangkan sikap rasa cinta tanah air misalnya mengikuti upacara bendera setiap hari Senin.

2) Memelihara ketertiban sekolah.

3) Tidak mampu menempatkan rasa persatuan dan kesatuan di sekolah.

4) Tidak mampu bekerjasama dalam hal apapun baik guru dan siswa maupun siswa dengan siswa/siswi.

ISSN: $2540-8038$ 
d) Kerakyatan Yang Dipimpin Oleh Hikmah Kebijaksanaan dalam Permusyawaratan/Perwakilan

1) Siswa tidak memaksakan
kehendak orang lain atau
kehendak temannya.

2) Menghormati setiap keputusan yang dicapai sebagai hasil musyawarah.

3) Melakukan musyawarah dengan akal sehat sesuai hati nurani yang luhur.

4) Siswa menghargai pendapat temannya.

e) Keadilan Sosial Bagi Seluruh Rakyat Indonesia

1) Siswa mengembangkan sikap adil terhadap sesama.

2) Menghargai hak orang lain.

3) Siswa suka berkerja keras dan kerja sama

4) Siswa mengembangkan sikap adil.

Berdasarkan hasil observasi di atas yang ditemukan oleh peneliti selama penelitian berlangsung di lapangan, bisa dikatakan bahwa siswa sudah memahami serta menunjukan sikap yang mengarah kepada nilai-nilai Pancasila, bahkan jika diangkakan sudah mencapai (95\%) siswa yang sudah memahaminya, maka dapat disimpulkan bahwa siswa sudah benar-benar memahami tentang nilai-nilai Pancasila tersebut. Upaya yang dilakukan oleh guru PKn tidak hanya menyampaikan materi tentang nilai-nilai Pancasila, melainkan juga mengupayakan supaya siswa menanamkan dan menerapkan contoh nilai-nilai Pancasila di lingkungan sekolah tersebut berdasarkan hasil wawancara yang dilakukan oleh peneliti upaya yang dilakukan oleh guru tersebut yaitu mengharuskan mengikuti upacara bendera setiap hari Senin, bergaul tanpa membedakan suku, ras, dan agama dan gender, menghargai sesama serta menanamkan hal-hal yang positif sesuai dengan nilai-nilai Pancasila. a) Ketuhanan Yang Maha Esa, Bangsa Indonesia menyatakan kepercayaannya dan ketakwaannya terhadap Tuhan Yang Maha Esa. b) Mengakui persamaan derajat, persamaan hak, dan kewajiban asasi setiap manusia, tanpa membeda-bedakan suku, keturunan, agama, kepercayaan, jenis kelamin, kedudukan sosial, warna kulit dan sebagainya. c) Mengembangkan persatuan Indonesia atas dasar Bhinneka Tunggal Ika. d) Menghormati dan menjunjung tinggi setiap keputusan yang dicapai sebagai hasil musyawarah. e) Menghormati hak orang lain. Dalam 
kegiatan dunia pendidikan guru adalah sebagai penggerak dalam dunia pendidikan. Dalam hal ini semua guru harus mengambil alih dalam mengkondisikan lingkungan sekolah guna mencapai penanaman nilai-nilai Pancasila yang lebih utama guru harus mengarahkan dan menjadi contoh yang baik guna tercapainya penerapan dan penanaman nilai-nilai Pancasila di lingkungan sekolah. Adapun berdasarkan hal yang didapat oleh peneliti hal yang dilakukan

dalam membuat siswa menjadi manusia yang lebih baik lagi yaitu:

1) Melaksanakan kegiatan ekstrakurikuler secara optimal dengan sarana pendukung yang tersedia kegiatan non-pejalaran guna dalam hal membimbing peserta didik dengan mengarahkan ke hal yang lebih aktif dan positif. 2) Melaksanakan kegiatan Imtaq, dengan menumbuhkan rasa kepercayaan dan merupakan bentuk perilaku manusia dalam hubungannya dengan Tuhan-Nya dengan sesama manusia. 3) Mendorong dan membantu siswa mengenali potensi dirinya dalam mengembangkan kreativitasnya secara optimal, yaitu mengembangkan kemampuan dasarnya serta kemampuan untuk menciptakan sesuatu yang baru serta mencapai nilai yang efektif.Upaya yang digunakan guru
PKn dalam menanamkan nilai-nilai Pancasila di SMA Negeri 1 Ketungau Tengah menerapkan nilai-nilai Pancasila yang dapat terinternalisasikan di lingkungan sekolah. Hal ini dilakukan dengan mengikutsertakan dan mewajibkan siswa untuk mengikuti upacara bendera setiap hari Senin.

Dalam penerapan dan penanaman nilai-nilai Pancasila ada beberapa faktor yang menghambat. 1) Siswa belum mengerti dan tidak mempunyai niat dalam menerapkan nilai-nilai Pancasila, sehingga seperti tidak terlaksananya penanaman nilai-nilai Pancasila. 2) Siswa tidak memiliki motivasi yang tinggi dalam menanamkan dan menerapkan nilai-nilai Pancasila sehingga menjadi salah satu faktor penghambat penanaman dan penerapan nilai-nilai Pancasila.Hal tersebut didukung oleh Dimyati dan Mudjiyono (2009: 80), menurut merekamotivasi adalah dorongan mental yang menggerakan dan mengarahkan perilaku manusia, termasuk perilaku belajar. Sedangkan

menurut Sudirman (2011: 75) bahwa motivasi juga dapat dikatakan serangkaian usaha untuk menyediakan kondisi-kondisi tertentu, sehingga seseorang mau dan ingin melakukan sesuatu, dan bila tidak suka, maka akan 
berusaha untuk meniadakan atau mengelakan perasaan tidak suka itu.3) Kurangnya minat belajar siswa sehingga menjadi salah satu faktor penghambat penanaman dan penerapan nilai-nilai Pancasila. Hansen dalam Susanto (2013: 57) berpendapat bahwa minat belajar erat hubungannya dengan kepribadian, motivasi, ekspresi, dan konsep diri atau identifikasi, faktor keturunan dan pengaruh eksternal atau lingkungan.

\section{Simpulan}

Dengan melihat hasil penelitian dan yang telah dibahas oleh peneliti dengan melihat dan berdasarkan hasil observasi, wawancara, dan dokumentasi mengenai analisis pemahaman siswa terhadap nilainilai Pancasila pada pembelajaran Pendidikan Kewarganegaraan siswa kelas XI SMA Negeri 1 Ketungau Tengah Tahun Pelajaran 2019/2020, maka dibuat kesimpulaan sesuai dengan prosedur penelitian ini sebagai nerikut:

1. Upaya guru dalam memberikan pemahaman siswa terhadap nilai-nilai Pancasila melalui proses pembelajaran PKn siswa kelas XI SMA Negeri 1 Ketungau Tengah tahun pelajaran 2019/2020, sudah

dilakukan dengan semaksimal mungkin dengan menanamkan nilainilai Pancasila di lingkungan sekolah tersebut serta mengupayakan siswa/siswi menerapkan nilai-nilai Pancasila tersebut.

2. Upaya guru PKn dalam memberikan pemahaman siswa terhadap nilai-nilai Pancasila melalui penerapan dan penanamannya di lingkungan sekolah pada pembelajaran PKn di SMA Negeri 1 Ketungau Tengah tahun pelajaran 2019/2020. Upaya guru sudah dilakukan dalam menerapkan dan menanamkan nilai-nilai Pancasila tersebut di lingkungan sekolah dengan melatih siswa/siswi tersebut untuk menerapkan dan menanamkan nilai-nilai Pancasila tersebut.

3. Faktor pendukung dan faktor penghambat guru PKn dalam memberikan pemahaman siswa terhadap nilai-nilai Pancasila pada pembelajaran PKn kelas XI SMA Negeri 1 Ketungau Tengah tahun pelajaran 2019/2020. Adapun faktor pendukung dan faktor penghambat dalam memberikan pemahaman nilai-nilai Pancasila, yaitu faktor pendukung yang meliputi ISSN: 2540 - 8038 
melaksanakan

kegiatan

ekstrakurikuler, melaksanakan

kegiatan Intaq, mendorong dan membantu siswa mengenali potensi dirinya dalam mengembangkan kreativitasnya secara optimal, serta kebijakan kepala sekolah. Sedangkan faktor penghambatnya yaitu siswa belum mengerti dan tidak mempunyai niat dalam menerapkan nilai-nilai Pancasila, siswa tidak memiliki motivasi yang tinggi dalam menanamkan dan menerapkan nilainilai Pancasila, kurangnya minat belajar siswa sehingga menjadi salah satu faktor penghambat penanaman dan penerapan nilai-nilai Pancasila.

\section{Daftar Rujukan}

Arikunto, (2010). Prosedur Penelitian Suatu Pendekatan Praktik. Jakarta: Rineka Cipta.

Effendi \& Tukiran, (2012). Metode Penelitian Survei.jakarta:LP3ES, 2012.

Gudnanto, dkk (2011). Pemahaman Individu Teknik Non Tes.

Kudus: Nora Media Enterprise.

Mudjiyono. 2009. Belajar dan Pembelajaran. Jakarta: PT. Rineka Cipta
Nuryaman \& Christina. 2015. Metodologi Penelitian Akuntansi dan Bisnis dan Teori Praktek. Bogor: Ghalia Indonesia.

Sugiyono, (2015). Metode Penelitian Pendidikan Pendekatan Kuantitatif, Kualitatif dan $R \& D$ : BandungCV. Alfabeta.

Sugiyono, (2016). Metode Penelitian Kuantitatif, Kualitataif, dan $R \& D$. Bandung: Alfabeta.

Sugiyono, (2011). Metode Penelitian Kuantitatif, Kualitataif, dan $R \& D$. Bandung: Alfabeta. 